\title{
We Choose What to Fear in Indonesian Horror Cinema
}

\author{
Achmad Ridwan Noer \\ Universitas Indonesia, Jakarta Timur, DKI Jakarta, Indonesia
}

\begin{abstract}
Horror movies in Indonesian cinemas have seen a recent surge of viewers despite being associated with exploiting sensualism under the blanket of horror. Meanwhile, the top ten viewed Indonesian horror movies in recent years managed to somewhat acquire the trust of Indonesians to come back to watch more horror movies in their favourite cinemas. This paper employs the qualitative content analysis method to better grasp what movie trailer elements are employed by the top 10 viewed Indonesian horror movies and see what are the similarities and differences in the elements of horror they present. Ultimately, as the market demands it, a natural selection for the kinds of horrors Indonesians watch is currently on going.
\end{abstract}

KEYWORDS

horror;

movie;

trailer; Indonesia; marketing

Keywords: horror; movie; trailer; indonesia; marketing

\section{INTRODUCTION}

The Indonesian horror movie trailers have been a remarkable tool to seduce the eyes and minds of the population to return to the cinemas. Despite having a rather negative view in the eyes of the usual moviegoers (Downes, 2014), there are ten Indonesian horror movies in 2017 and 2018 which are expected to restore the nation's thrust in the genre. As a marketing an effective marketing tool, the trailers of these movies played a role to terror millions of people in the theatre. As often as the movies get their reviews, the trailers do not. Even in YouTube, where most of the production houses such as Rapi Films, in which channel the trailer for Pengabdi Setan (2017) is published, the platform users say their opinions, praises, and critiques about the movie. While the purpose of the trailer is to draw the viewers' attention to talk about the movie, I think it is just fair to also review the trailer itself. The method employed here is the qualitative analysis method. The goal of this study is to see what these Indonesian movie trailers have in common. This paper will discuss what elements of horror are present in the trailers of Indonesian horror movies. The trailers in question would be the trailers for Pengabdi Setan (2017), Suzzanna: Bernapas dalam Kubur (2018), Danur: I Can See Ghosts (2018), Jailangkung (2017), Asih (2018), Sabrina (2018), Mata Batin (2017), Kuntilanak (2018), The Doll 2 (2017), dan Sebelum Iblis Menjemput (2018). With the common prejudice of the horror movies from the perspective of the population in general; that the genre is filled with noneducative contents, unrealistic ghosts, unnecessary over sensualized scenes, and 
promoting supernatural aspects of life (Downes, 2014); this paper will discuss what elements are present in these movie trailers which have overcome those prejudices, and thus bringing millions to their favourite theatres.

First of all, I wish to describe what a movie trailer does. Practitioners and scholars share the common idea that a movie trailer is a sample of a movie (Dreyer, 2018; Finsterwalder et al., 2012; Karray \& Debernitz, 2015; Garrett, 2012). It shows everything a movie has; a plot, actors/actresses, information in regards to which studio produced the movie, background sound and music, and the general premises of the genre of the movie. In 60 seconds up to 180 seconds, this audio-visual form of an advertisement conveys a lot of information about an upcoming movie to get people talking about it or to get their attention. Thus, movie trailers do this better than any other form of advertisement to market a movie.

In the horror movie genre, the structure is quite the same (Dreyer, 2018; Karray \& Debernitz, 2015; Flanagan, 2014). The first part of a trailer mainly consists of the studio, the production house, the director, and the casts. The second part of a horror movie trailer consists of an introduction of the conflict in the movie. The third part of a horror movie trailer commonly shoes an escalation of the conflict shown in the second par or reinforcing the genre of the movie by enacting the main attraction of the movie which is escalating from the second part.

The similarities in the audio-visual part of the Indonesian horror movie trailers, at least from the ten movies whose trailers we are about to discuss here, lie in them employing a rather dark tone colour to present the visuals, as is common within the genre both in Indonesian and international horror movies and trailers. Meanwhile, the background music and sound are slowly intensifying from the introduction up to the third part of the trailers, which are also common within the genre (Redfern, 2020). Redfern (2020) pointed out that these movie producers may also go out of their way to mash-up sounds and music so that their movies can have a set of sound effects and music specially tailored to the movies themselves.

To grasp what a trailer conveys, we need to know what is in the trailer itself. A trailer generally shows the audience who plays in the movie, what studio and production house are involved in making it, and its background music and sound that enhance the visual experience (Garrett, 2012). It is not rare to see what achievements any of the casts have, for instance, some trailers would like their audience to see that the director has been nominated for or has won an award for their previous movies. The concept of star power here plays a role in a movie trailer because the fame or achievement of the casts or director may get the attention of the audience. Another thing that may also spice up an Indonesian horror movie trailer is a revealing fact where the idea or the story came from. Even further, some of those trailers also market the movie themselves by having the title of the movie as lore-friendly as possible so that the audience may relate to it better. For 
example, the Indonesian horror cinema has produced several movies which are based on true events or real-life location, such as Hantu Jembatan Ancol (2008), Terowongan Casablanca (2007), and Lawang Sewu (Dendam Kuntilanak) (2007). The plot within the trailers, however, may have been using the same formula for the most part; introduction, conflict, and escalation of the conflict.

Shortly, what we may watch in an Indonesian horror movie trailer as a marketing tool are the casts, the studio, a plot, some cut scenes of the conflict and its escalation along with progressively intensifying music and sound.

The fame and achievements of the stars, the music, the plot, and among all those items in an Indonesian horror movie trailer we listed before, have we ever wondered which one of those attracted us to watch those movies? While the answer might just be very subjective, the most objective way we can have to determine why we watch those movies is to draw the basic premise of any horror movies; horror (Griffiths, 2015). The horror advertised via these trailers is the results of a lot of things, whether it is a strange anomaly in nature, a supernatural phenomenon we only hear but never witness, or a very unlikely out-worldly thing is happening which we have never imagined before (Prohászková, 2012). We watch these horror movies because of what the genre has to offer; the horror itself (Ndalianis, 2012). We believe in the genre's power to amuse us through disgust, terror, fear, and, in some ways, making us feel we live in the horror story we are watching or feel that those scary elements from the movie are with us. The genre can provide us with a lot of mixed feelings.

\section{METHOD}

The method employed in this study is the qualitative content analysis. The first step in this research is to line up the trailers for ten most watched Indonesian horror movies.

Table 1. Ten Most Watched Indonesian Horror Movies

\begin{tabular}{|l|l|l|c|}
\hline \multicolumn{1}{|c|}{ Title } & \multicolumn{1}{|c|}{ Year } & \multicolumn{1}{c|}{ Director } & Viewers \\
\hline Pengabdi Setan & 2017 & Joko Anwar & 4.206 .103 \\
\hline $\begin{array}{l}\text { Suzzanna: Bernapas } \\
\text { dalam Kubur }\end{array}$ & 2018 & Rocky Soraya; Anggy Umbara & 3.346 .185 \\
\hline Danur: I Can See Ghosts & 2017 & Awi Suryadi & 2.736 .391 \\
\hline Jailangkung & 2017 & Jose Poernomo; Rizal Mantovani & 2.550 .271 \\
\hline Asih & 2018 & Awi Suryadi & 1.714 .798 \\
\hline Sabrina & 2018 & Rocky Soraya & 1.337 .510 \\
\hline Mata Batin & 2017 & Rocky Soraya & 1.282 .557 \\
\hline Kuntilanak & & & 1.236 .000 \\
\hline
\end{tabular}




\begin{tabular}{|l|l|l|l|}
\hline The Doll 2 & 2017 & Rocky Soraya & 1.226 .864 \\
\hline $\begin{array}{l}\text { Sebelum Iblis } \\
\text { Menjemput }\end{array}$ & 2018 & Timo Tjahjanto & 1.122 .187 \\
\hline
\end{tabular}

Source: Samudro (2019)

The most watched Indonesian horror movie list is curated by Tirto.id based on the information bank on filmindonesia.or.id. Filmindonesia.or.id itself is a database founded and operated by the Indonesian movie makers to act a database for Indonesian movies regardless of genre.

The second step is to identify the plot of the trailers. If anything, a movie trailer shows a sequence of actions that make a complete plot, letting the audience know what begins and what ends by the end of the trailer. Since the interest of this paper is to reveal what elements or what combination of elements produce the horror in the trailers of ten most watched Indonesian horror movies. In identifying the plot, the audio and visual ques will also be considered since the horror genre also develops intensity by tailoring sounds and music to better suit the mood of the trailers. This second step will primarily point out the key events or aspects of the plot. The third step, then, is to make sense of the combination or to conclude the trailer based on what it is showing and what it tells us. After these three steps, we will discuss how those elements of fear be relatable as to attract millions of people.

\section{Pengabdi Setan (2017)}

Pengabdi Setan (2017) is directed by Joko Anwar and produced by Rapi Films and CJ Entertainment. The trailer begins with displaying pitch black scene with a serene sound of a bell chime with static radio noises followed by a song. It shows a sick woman living with her families. The background music starts with a rather non intense rhythm, engulfing the sense of care between family members. The sick woman, identified as Ibu passes away and the family members show sadness, remembering her. A young boy, identified as Adik, is terrified of his view from his bedroom which directly gaze at the cemetery. A man, identified as Bapak, tries to reassure Adik that people who have passed away cannot disturb him, the living. His oldest brother is seen sitting restlessly on his bed, trying to figure out why his radio does not work as intended. As the sound of a bell chime can be heard, his radio turns on playing the song from the introduction, revealing a woman dressed in white is sitting on a chair by his bed, startling him. As the family members begin to experience supernatural activities, the background music intensifies. The older brother is shown dragged away, Kakak is shown terrified of the woman dressed in white, Bapak dives into a well in their house to save Adik from drowning. As the trailer reaches its climax, the music intensifies, and the final scene depicts Kakak directly confronts the woman in white, with a lot of sharply dressed people with opened black umbrellas. Before the trailer ends, a bell chime can be heard, followed by the same static radio sounds before the same song plays the same verse again. 


\section{Suzzanna: Bernapas dalam Kubur (2018)}

Suzzanna: Bernapas dalam Kubur (2018) is directed by Rizky Soraya and Anggi Umbara and produced by Soraya Intercine Films. The trailer begins with a recital of the Al-Quran by a character with his wife, who is experiencing a disturbance. The unease feeling grows within the characters. Home invaders are shown formulating a plan, with it the background music begins to intensify gently. A group of characters are discussing a mythical creature named Sundel Bolong as a vengeful spirit with an unfinished business. A conflict between the home invaders and the wife character ends up in violence and murder. The murdered woman is revealed to be transforming into the mythical Sundel Bolong, surprising the group of characters who are discussing the myth. The vengeful spirit, Sundel Bolong, begins to terror the terrorists that murdered her one by one. The background music intensifies with rhythmical value as to pause when the vengeful spirit laughs, revealing her exposed, and rotting back. As the plot reaches climax, the cut scenes of what is done to her body by each home invader can be seen before she takes revenge to her murderer.

\section{Danur: I Can See Ghosts (2017)}

Danur: I Can See Ghosts (2017) is directed by Awi Suryadi and produced by Pichouse Films. The trailer begins with slow rhythm background music while the visual depicts a lonely person, hinted to be surrounded by spirits. A child song can be heard playing in the background. The child in the introduction is now a grown person, the loneliness dissipates because of her interaction with other people. The background music also changes as she is shown as a grown person. The male the girl interacted with hinted that they are lonely while she insists there are people with them there, the music also intensifies further as their interaction hinting there are people the male character cannot see but she can. The background music returns to slow rhythm as before as the girl begins to accept the loneliness she had in the beginning, revealing that there are people only she can connect with in the house.

\section{Jailangkung (2017)}

Jailangkung (2017) is directed by Jose Poernomo and Rizal Mantovani and produced by Screenplay Films and Legacy Pictures. The trailer begins with a group of characters discussing an old wooden doll-like object, presented by a man. A character's father is shown suffering from a mysterious disease in regards to the ancient Javanese culture related to the previously shown old wooden doll-like object. The background music slows down while a group of characters enter a mansion and begin exploring. The man with the illness is told to be visiting a mansion some times in the past and the characters are now set to go there with a plane. An ancient ritual using a rather similar old wooden doll-like object takes place whilst the background music begins to intensify. The foreign object during the ritual moves unexpectedly and another music begins to overlap with the background music. As the plot of the trailer reaches climax, the plot thickens with information related to the old wooden object, the summoning ritual related to that object, 
the disease that the ritual entails, even the spirit they accidentally summon after the ritual.

\section{Asih (2018)}

Asih (2018) is directed by Awi Suryadi and produced by MD Pictures. The trailer begins with information that tells the audience that this movie is a prequel to Danur: I Can See Ghosts (2017) in a similar manner the title Danur: I Can See Ghosts is introduced. A scene from Danur: I Can See Ghosts plays, indicating the relation with this movie. The plot for Asih begins with a mother and her infant, shown under a very big tree. A narration begins while the mother and her infant are under the rain, approaching the big tree. The narration with female voice speaks of a woman named Asih. The narration is now voiced by a male, as if to convey his perspective. In this introduction part, both narrators discuss who this woman named Asih is, because she is a mystery to them. The plot moves to show a woman giving birth, assisted by a local nurse, or a bidan, and her husband. As the woman goes into labour, a pair of strange hands begin to creep in their direction but nobody notices. After the labour, the wife asks her husband to bury the placenta of the baby and he goes to bury it. The narration comes back again, still discussing the mystery surrounding this Asih person. As a steadily increasing volume, in the second part of the trailer a song can be heard. The song is similar to the one children song in Danur: I Can See Ghosts. In this part, the spirit of a woman dressed like the mother character from the introduction can be seen travelling unnoticed by both the husband and the wife. The husband is shown going outside to check what is happening near their house only to find a woman-like figure consuming their child's placenta. The voice of narrator is missing, the background music intensifies as the plot reaches climax and disappear when the final moment of the trailer is revealed. The spirit of a woman is shown to be the reason behind some supernatural phenomena within their household. The final moment of the trailer is revealed when the wife character stops the movement of a rocking chair only to be loudly screamed at by the woman spirit, now able to fully manifest to scream at the wife.

\section{Sabrina (2018)}

Sabrina (2018) is directed by Rocky Soraya and produced by Hitmaker Studios. The trailer begins with a child playing with her doll, while her mother is coming to get her to go have breakfast together. Her mother thinks that it is cute that she plays dress-up with the doll, so she closes the door to her room to let her play. Soon after the child begins conversation with the doll, her mother opens the door again to check on her but nothing happens. When she closes the door once again it is revealed that a strange person is sitting with her daughter for a hair-styling treatment. The background music is not intense in this introduction part, but several sudden noises do occur in relation to the sudden appearance of the spirit character depicted by the strange person. The story of the Sabrina doll is explained by a male narrator, hinting that the father of the girl earlier is speaking. The Sabrina doll is revealed to be a memento for the family, it is a token to remember the previous child the mother lost in a car accident. The child is shown to be playing with a board to connect with spirits and a smartphone-like device to see if there 
is any apparition near her, but she is taken away into a cabinet. The mother and daughter can be shown having an interaction, she tells the girl what she does whenever she misses her passed away daughter and hope the same treatment can lift her spirit when the daughter misses her passed away mother. The background music intensifies as the world seems to be growing darker. The male narrator switches voices with another male narrator and the supernatural phenomenon takes place, one after the other. The saviour character, portrayed by another male, possibly the later male narrator, reveals the identity of the supernatural entity that has been disturbing the family. As the trailer reaches its climax, the music begins to intensify with several sudden noises whenever a supernatural character is shown on screen. The spirit is shown taking control of the bodies of the parents while the child is missing. The last scene of the trailer shows the spirit crawls on the walls of the house as if it is now in control of the house.

\section{Mata Batin (2017)}

Mata Batin (2017) is directed by Rocky Soraya and produced by Hitmaker Studios. The trailer begins with showing a cemetery and a female narrator begins to speak. She tells the audience who she is and what is the purpose of their visit to the cemetery is. She and her sister are forced to move back to their place growing up a long time ago. The little sister is shown unease because she can feel the presence of others that the older sister cannot. The sister possesses a talent to see the spirits wandering around the house, therefore she is disturbed by them. Supernatural events one after another occurs but the older sister cannot comprehend what they are and the little sister is brought to a supernatural expert, revealing that she has her 'third eye' open and that allows her to see spirits normal people would not be able to. The older sister opens up her 'third eye' with the help of the supernatural expert, that way she can finally see what her sister is always able to see. One by one, she also experiences disturbing interaction with the spirits within the house. The music slowly intensifies in this part while the sound of thunder and rain continuously rumble in the background. Some of the spirits in the house are not only disturbing to them both, but some of them are also hostile towards the two sisters. The final scene of the trailer reveals one of the spirits is chopping something, but when the older sister does not see, the spirit moves quickly to close up to her with her knife ready to slash.

\section{Kuntilanak (2018)}

Kuntilanak (2018) is directed by Rizal Mantovani and produced by MVP Pictures. The trailer begins with a child and a mirror, a text animation runs "a family" as the screen shows a family parting with the mother. The parents leave their kids under a sitter care. One by one, the kids an odd experience because the want to start an exploration in a somewhat abandoned mansion. Another running text runs "an accident", following a kid runs up a door and slams it shut, but a rather disfigured looking foot stops the door from closing and the foot begins to bleed. The background music develops into a rather more intense note than before. The cut scenes go from one kid experiencing disturbance to another as they are separated from each other and the sitter. The sitter who is in charge 
of the kids is shown in retrospect that she will take good care of the kids, while she is also shown to be disturbed and helpless against the creature, they accidentally set free by being in the mansion and go to a somewhat antique looking mirror. They are chased by the supernatural figure who uses the mirror like a portal to travel between worlds, and this final scene is accompanied by a suspenseful music and background sounds to facilitate the creature's terror and supernatural power.

\section{The Doll 2 (2017)}

The Doll 2 (2017) is directed by Rocky Soraya and produced by Hitmaker Studios. The text animation in the opening sequence of the trailer indicates that this movie is a sequel to a previous movie titled The Doll in The Doll Series. The introduction shows a family in a car accident that tragically takes the life of the passenger in the backseat. The couple in the front seat are revealed to be the parents of the girl sitting in the passenger seat, holding her doll. When the mother character is taking a shower, she is assisted by a pair of disfigured hands. The grieving family members are seen placing the doll in the place of her daughter. The mother begins experiencing odd supernatural phenomenon whenever she is near the doll. She explains to her husband that she feels that Kaila, the passed away daughter, is still with them in the house and trying to connect with them. A song is playing in the background but the volume is weaker than the background music. A character that acts like a supernatural expert explains that the mother may be right that the spirit of Kaila may be trying to communicate with them. The song playing in the background is intensifying and competing with the background music as the doll is shown more often than before, indicating the purpose of the doll. The doll is now a medium to communicate with Kaila, with the help from the supernatural expert. A ritual ceremony takes place to subjugate the doll as the sole medium to communicate with the couple. A rather disfigured character takes the place of the doll while looks like the doll's appearance. A transformation of the doll into the disfigured creature and the terror it causes becomes the climax of the trailer, accompanied by the song before and the rather intense background music along with the background sound effects whenever the creature comes.

\section{Sebelum Iblis Menjemput (2018)}

Sebelum Iblis Menjemput (2018) is directed by Timo Tjahjanto and produced by Sky Media and Legacy Pictures. The trailer begins the character Alfie gets a phone call that starts the mystery surrounding her family. The background music is rather peaceful as to allow the character to converse, revealing one bit of the whole mystery surrounding them. In need of financial assistance and a rather strange illness of a family member, Alfie heads to an abandoned looking villa. The old villa looks abandoned for a long time as to allow vines and roots to grow all over and the plants there are malnourished. The door to the interior is creaky and dirt is all over. Alfie begins investigating the old villa to look for clues what may have gotten her father ill. A locked door to the basement is opened. A disfigured looking figure is shown by bursting out of the basement to where Alfie and the other members of the family meet up to have discussion about what this old villa means. 
The final part of the trailer begins with a reanimation of the characters shown tortured and killed. In the basement Alfie finds a woman she accuses of the reason behind the mysterious illness and the death of the other family members. This final part shows a series of killing and reanimation of the dead, with Alfie in the center confronting the woman she believes started it all.

\section{RESULT AND DISCUSSION}

Each of these trailers have a plot of their own. Each of them presents us, the audience, with a promise of horror, that we will have a certain degree of disgust, fear, and also amusement at the same time. Across the titles, there are several things these trailers have in common, aside from the promise of horror. As Dreyer (2018) pointed out, most of the trailers for horror movies employ the approach where a character has to be violated in some way to trigger the plot to develop. The Indonesian horror cinema has also employed the same pattern, what can be said different from all the international horror movies are the story or the element of horror may just be very relatable to Indonesian viewers. Let us have a look at what each of the trailer presents us as the element of horror.

As noted in the beginning of the trailer for Pengabdi Setan (2017) the bell chime and the static radio might have a significance in the trailer, and it is to present us with an opportunity to brace ourselves because in the following times the bell chimes and the radio produces static sounds, a surprise appearance of the woman in white takes place. The woman in white, though in the trailer is not clear who she might be, is displayed similar to the mother who passed away. The only clue related to this woman in white is the photograph of a woman in white which indicates the woman in white actually is the dead mother presented in a reanimation state, displaying the highlight of her life such as the one in the photograph. This woman in white also resembles what is shown in the trailer for Suzzanna: Bernapas dalam Kubur (2018). She is murdered by home invaders after previously shown as happy as she could be, with her husband and expecting a child. The vengeful spirit, Sundel Bolong, takes her place to return to her husband and exert violence upon the home invaders. The reanimation as a plot point also becomes the reason behind everything that goes wrong in the trailer of Sebelum Iblis Menjemput (2018). Alfie fears for her life and is struggling to find the truth behind the woman whose drawing she saw and whatever happened in the past that involved her father. Each of these three trailers differs in what caused the reanimation; we do not have a clear clue what Pengabdi Setan has as a cause for a reanimation for the woman in white, we do have a myth that revolves around the group of people discussing what will happen to a pregnant mother who dies a tragic death in Suzzanna: Bernapas dalam Kubur, and we have a seemingly ritualistic vibe in the locked basement, where Alfie finds herself in, in the climax of the trailer for Sebelum Iblis Menjemput. Though the causes are different, three of the ten most watched Indonesian horror movies have reanimation as the same 
element of horror in the trailer. At least, the reanimation might not be the element of horror presented, but what the reanimation, with or without any rituals, entails is.

In the trailer for Danur: I Can See Ghosts, we are provided with a seemingly happy child playing but stopped by a woman-like figure from leaving. The premise of this trailer is that we are watching how a person with supernatural ability goes about her daily life without perfectly aware that people around her, normal people, cannot see spirits like she can. The trailer for Mata Batin, too, employs the same strategy. The little sister is somewhat born with the ability to see the spirits in their old house, and therefore she is disturbed more than her older sister who only can see the same spirits within their old house after she asks the supernatural expert to open up her 'third eye'. In a similar way, the trailer for Asih also shows that the ability to see spirit. However, in Asih, the wife and her husband only gradually begin to feel the existence of the spirit. The fully manifest spirit by the end of the trailer shows that the spirit's ability to manifest to interact with them progresses as the baby grows older, beginning from the moment the wife goes into labour. This myth of 'third eye', or the sixth sense, or, as the myth entails, 'mata batin' is rather similar from one to another in terms of the function of this supernatural object; to see spirits.

The spirits manifestation into an object is shown in the trailer the Doll 2. As the trailer shows, the doll functions as a medium for the mother to connect with her daughter, with the help of a supernatural expert. Rather than the spirit manifests the doll, I would like to argue that the doll itself become some sort of a portal so the spirit can go through, allowing it to travel between worlds. This portal is also a plot point in the trailer for Kuntilanak, where the portal is an old antique mirror that the children and their sitter visited. The group have to deal with this spirit coming from the antique mirror without the help from any supernatural experts. However, this is not the case with Jailangkung where in the intensified part of the trailer, the characters do receive insights on how to deal with the spirit running amok in the mansion, as shown in the trailer. The case of Jailangkung is quite similar to The Doll 2 in which the wooden doll-like object is the reason behind the misfortune and accidents that befall the characters. Meanwhile, the trailer for Sabrina uses the Sabrina doll as a memento for a child to remember her mother whenever she misses her. Although, Jailangkung and Sabrina has a difference in which the doll in Jailangkung is used to communicate and summon spirits who later in the trailer runs amok, Sabrina shows that the Sabrina doll is there watching the misfortune happens to the character. In this sense, the Sabrina doll might function like a camera which feed transfers to a world the spirit character comes from.

Violence, communication with the other side, and rituals to get what someone wishes for have been the reason for all these supernatural occurrences. Asih may not categorize in them, in terms of the point of view where in the trailer, the spirit is looking for a way to manifest herself so she can be together with her child even though the trailer shows that the baby there is not hers. These horror elements of reanimation, communicating with 
spirits, or rituals are so commonly produced and reproduced, even more so if the movies promote any of local ghosts such as kuntilanak (Permana, 2014). The production and reproduction of this genre, however, is so rapid that in 2018, there were two movies with Jelangkung in their title, namely Jailangkung 2 which is directed by Rizal Mantovani and Jose Poernomo and Tusuk Jelangkung di Lubang Buaya which is directed by Erwin Armada.

The Indonesian horror cinema has provided us with thrills, waiting for us to reap them. There are urban legends, myths, and pop culture to be the inspiration for the next horror movies that should give people the thrill and dread they are looking for (Prohászková, 2012; Griffiths, 2015; Grant, 2010). The tendencies of the audience to seek this kind of thrill might not just be from the story and the amusement they can take from the movies, but also to watch how dread and fear are presented on the big screen (Martin, 2019).

There is also a change in paradigm of how a trailer for an Indonesian horror movie is presented. Back in 2001, the first ever Indonesian horror movie to return to theatres, Jelangkung (2001), brought back people to theatres to once again see a horror movie in the big screen (Permana, 2014). Then, the production of horror movies began to take flight even up to 2011 where there was an absence of imported movies (Kristanto \& Pasaribu, 2011). The strategy to put up sensual content in the trailers was used then, because it surprisingly was effective. However, such concept no longer serves as a selling point because there were several factors, the first one is the production of sensual horror movie stopped and the second one it that the viewers do not watch them anymore. Thus, this brings us to the latest trend in horror movie advertising when it comes to the trailers; be as horrific as possible. The trailers from the ten most watched Indonesian horror movies do not have any sensual concept embedded within them and this may just be what the viewers want. Finsterwalder et al. (2012) found that it is true that the trailers do make a certain expectation of the movies, and therefore in this paper it is concluded that based on the declining rate of both the sensualized Indonesian horror movie and the viewer of such category, the Indonesian horror cinema is dictating what it wants.

\section{CONCLUSION}

Ten of the most watch Indonesian horror movies explored the concepts of reanimation, manifestation through objects, and having the ability to see spirits. These concepts are common within the horror genre both internationally and nationally. The stories told in the trailer allow the audience to select what to fear when they watch. The relatable stories of these ten trailers delivers what horror elements are most produced in Indonesia. With the horror genre back on theatres and none of the sensualized horror movies in place, the situation forces the trailers to be made as creatively as possible, as relatable as possible, and as familiar as possible. The title Kuntilanak (2018) and Jailangkung (2017) have been reproduced a few times since 2001, and this signals the competition for the local ghosts 
to find the nearest portal we name theatres because apparently, the public demands that more local stories become developed into movies. Even these ten movies are based on the stories we Indonesians are familiar with. We know them because as children we cannot and may not play outside after dusk, so that the evil spirit will not kidnap us. We know them in our schools based on a baseless rumor about a spirit in the school bathroom. The idea for the next horror movie might just have been the empty chair in our school back then, only if the movie Bangku Kosong had not came out in 2002.

The horror elements advertised in these trailers have been several times over used to promote other movies. The title Jelangkung has been a reboot for a few times. The title Kuntilanak even had several horror comedy movies made out of it. However, the most amazing part, personally for me, is that the formula needs to employ some sort of a supernatural element for these trailers to get the attention of so many people. Setting aside the typical horror stereotype that it is somewhat a sexist thing or it has something to do with women (McKenzie et al., 2018) like in Pengabdi Setan and Asih, there is not much of alternatives available on the market for people to see. The psychological horror, such as Modus Anomali in 2012 or Pintu Terlarang in 2009, is still not considered an alternative for a horror movie, even though both are popular up to this day. This condition to choose only ghosts to be filmed on screen may one day change. The popularity of supernatural elements to be incorporated into big screen for the Indonesian horror cinema is still a popular thing to have (Park, 2018). There are a lot of other alternatives instead of playing with ghosts every year, which is surprisingly the core idea of Danur: I Can See Ghosts. I would like to end this paper with a rather hopeful tone that a more diverse options will be available in the future for the Indonesian horror cinema, after all, Indonesians themselves cannot stop bringing new ideas of what to fear.

\section{REFERENCES}

Anwar, J. (Director). (2017). Pengabdi Setan [Film]. Rapi Films.

Downes, M. (2014). Horor Kampungan versus Moralitas Populer: Mempertanyakan Definisi Film Nasional yang Bermutu. Jurnal Komunikasi Indonesia, III(1), 13-24. https://doi.org/10.7454/jki.v3i1.7844

Dreyer, C. (2018). Crafting Fear: The Horror Film Trailer (Publication No. 2936) [Honor Thesis, Western Michigan University].ScholarWorks@WMU.

Finsterwalder, J., Kuppelwieser, V. G., \& Villiers, M. D. (2012). The effects of film trailers on shaping consumer expectations in the entertainment industry-A qualitative analysis. Journal of Retailing and Consumer Services, 19(6), 589-595. https://doi.org/10.1016/j.jretconser.2012.07.004 
Flanagan, M. (2014, May 23). How to Edit a Trailer That Will Get Your Film Noticed. Microfilmmaker Magazine. https://www.microfilmmaker.com/tipstrick/Issue14/Edit_Trl.html

Garrett, S. (2012, January 13). The Art of First Impressions: How to Cut a Movie Trailer. FILMMAKERMAGAZINE. https://filmmakermagazine.com/37093-firstimpressions/

Grant, B. K. (2010). Screams on Screens: Paradigms of Horror. Loading..., 4(6).

Griffiths, M. D. (2015, October 29). Why Do We Like Watching Scary Films? Psychology Today. https://www.psychologytoday.com/us/blog/in-excess/201510/why-dowe-watching-scary-films

Karray, S. \& Debernitz, L. (2015). The Effectiveness of Movie Trailer Advertising. International Journal of Advertising Research, 36. https://doi.org/10.1080/02650487.2015.1090521

Kristanto, J. \& Pasaribu, A. J. (2011, Desember 30). Catatan 2011: Menonton Penonton. filmindonesia.or.id. http://filmindonesia.or.id/article/catatan-2011-menontonpenonton

Mantovani, R. (Director). (2018). Kuntilanak [Film]. MVP Pictures.

Martin, G. N. (2019, 10 18). (Why) Do You Like Scary Movies? A Review of the Empirical Research on Psychological Responses to Horror Films. Frontiers in Psychology, 10, 2298. https://doi.org/10.3389/fpsyg.2019.02298

McKenzie, M., Bugden, M., \& Webster, A. (2018). ADVERTISING (IN)EQUALITY: THE IMPACT OF SEXIST ADVERTISING ON WOMEN'S HEALTH AND WELLBEING. Women's Health Victoria.

Ndalianis, A. (2012). The Horror Sensorium: Media and The Senses. McFarland Publishing.

Park, M. (2018). The Aesthetics and Psychology Behind Horror Films (Publication No. 1030) [Undergraduate Thesis, Long Island University]. Digital Commons @ LIU.

Permana, K. S. A. (2014). Analisis Genre Film Horor Indonesia dalam Film Jelangkung (2001). COMMONLINE DEPARTEMEN KOMUNIKASI, 3(3), 559-573.

Poernomo, J. \& Mantovani, R. (Directors). (2017). Jailangkung [Film]. Screenplay Films \& Legacy Pictures. 
Prohászková, M. V. (2012). The Genre of Horror. American International Journal of Contemporary Research, 2(4), 134-142.

Redfern, N. (2020). Sound in Horror Film Trailers. Music, Sound, and the Moving Image, 14(1), 47-71. https://doi.org/10.3828/msmi.2020.4

Samudro, A. (2019, August 7). Daftar 10 Film Horor Indonesia dengan Jumlah Penonton Terbanyak. Tirto.id. https://tirto.id/daftar-10-film-horor-indonesia-denganjumlah-penonton-terbanyak-efRg

Soraya, R. (Director). (2017). Mata Batin [Film]. Hitmaker Studios.

Soraya, R. (Director). (2017). The Doll 2 [Film]. Hitmaker Studios.

Soraya, R. (Director). (2018). Sabrina [Film]. Hitmaker Studios.

Soraya, R. \& Umbara, A. (Directors). (2018). Suzzanna: Bernapas Dalam Kubur [Film]. Soraya Intercine Films.

Suryadi, A. (Director). (2017). Danur: I Can See Ghosts [Translated title] [Film]. Pichouse Films.

Suryadi, A. (Director). (2018). Asih [Film]. MD Pictures \& Pichouse Films.

Tjahjanto, T. (Director). (2018). Sebelum Iblis Menjemput [Film]. Sky Media \& Legacy Pictures. 